\title{
Independensi Kekuasaan Kehakiman Berdasar Undang-Undang Dasar 1945
}

\author{
Sofyan Jailani
}

Mahasiswa Bagian Hukum Tata Negara FH Unila

\begin{abstract}
Abstrak
Artikel ini bertujuan untuk memaparkan apa yang dimaksud Kemerdekaan pada Kekuasaan Kehakiman yang dijalankan Mahkamah Agung dan Mahkamah Konstitusi Pendekatan secara normatif serta dengan analisis Perspektif mampu menjabarkan Kemerdekaan pada Kekuasaan Kehakiman yakni kemerdekaan dalam memberikan putusan, internal hakim, serta sistem dalam rangka menegakan keadilan dan kepastian hukum. Karena independensi kekuasaan kehakiman merupakan salah satu dasar untuk terselenggaranya pemerintah yang demokratis di bawah rule of law.
\end{abstract}

Key word: Kekuasaan Kehakiman, Kemerdekaan, dan Hakim

\section{Pendahuluan}

Pasal 1 ayat (3) Undangundang Dasar Negara Republik Indonesia Tahun 1945 (UUD 1945) menegaskan bahwa Negara Kesatuan Republik Indonesia adalah negara hukum.

UUD tahun 1945 merupakan sumber dari hukum positif yang berlaku di indonesia. Dengan munculnya konsep rechstaat dari Freidrich Julius Stahl, yang diilhami oleh Immanuel Kant. Menurut Stahl unsur-unsur negara hukum (rechstaat) $^{l}$ adalah 1). Perlindungan Hak-hak Asasi Manusia; 2) Pemisahan atau Pembagian Kekuasaan untuk menjamin hak-hak itu.

Pada waktu yang hampir bersamaan muncul pula konsep negara hukum (rule of law) dari A.V. Dicey yang mengemukakan unsur dari pada rule of law adanya supremasi aturan-aturan hukum (supremacy of the law) yaitu tidak adanya kekuasaan yang sewenang-

${ }^{1}$ Ridwan Hr, Hukum Administrasi Negara, (Jakarta: PT. Raja Grafindo Persada, 2002), hlm 3 . wenang (absence of arbitrary power). Adapula konsep negara hukum pancasila ${ }^{2}$ dimana ciri-ciri hubungan yang erat antara agama dan negara yang bertumpu pada ketuhanan yang Maha Esa kebebasan agama dalam arti positif ateisme tidak dibenarkan dan komunisme dilarang asas kekeluargaan dan kerukunan dengan unsur utamanya adalah sistem konstitusi, persamaan dan peradilan yang bebas.

Salah satu materi muatan atau bidang yang diatur dalam bidang UUD tahun 1945 adalah mengenai kekuasaan kehakiman. Sejalan dengan ketentuan tersebut maka salah satu prinsip penting dari negara hukum adalah adanya jaminan penyelenggaraan kekuasaan kehakiman yang merdeka, bebas dari pengaruh kekuasaan lainya untuk

\footnotetext{
2 Azhary, H.M. Tahir, Negara Hukum: Suatu Studi tentang Prinsip-Prinsipnya, Dilihat dari Segi Hukum Islam, Implementasinya pada Periode Negara Madinah dan Masa Kini. ( Bogor: Kencana, 2003)
} 
menyelenggarakan peradilan guna menegakan hukum dan keadilan ${ }^{3}$.

Pembagian kekuasaan negara kedalam lembaga-lembaga negara juga sejalan dengan logika demokrasi yang menghendaki diferensiasi peran antarlembaga negara dan situasi saling mengawasi antarlembaga negara guna menghindari pemusatan dan penyalahgunaan kekuasaan, pengaturan dan pembatasan kekuasaan itu juga menjadi ciri konstitusionalisme dan juga merupakan tugas dari konstitusi sehingga kemungkinan kesewenangwenangan kekuasaan dapat dikendalikan. ${ }^{4}$

Kekuasaan kehakiman sejak awal kemerdekaan diniatkan sebagai cabang kekuasaan yang terpisah dari lembaga-lembaga politik seperti Legislatif dan Presiden serta memiliki hak untuk menguji yakni hak menguji formil (formele toetsingrecht) dan hak menguji meteril (materiele toetsingrecht). ${ }^{5}$

Sebelum eksisnya negara hukum modern Imanuel kant menyebutkan bahwa disamping adanya perlindungan Hak Asasi Manusia, juga terdapat pemisahan kekuasaan dalam negara yang menjamin keberadaan lembaga yang berfungsi memisahkan persengketaan warga dalam negara penjaga malam (klassiekerechtstaat). ${ }^{6}$

\footnotetext{
3 Jimly Asshiddiqie, Pokok-pokok Hukum Tata Negara Indonesia, (Jakarta: PT Bhuana ilmu populer, 2007), hlm 512

4 Jimly Asshiddiqie, Konstitusi dan Konstitusionalisme Indonesia, (Jakarta: Sinar Grafika, 2010), hlm 138

5 Abu Daud Busroh, Sistem Pemerintahan Republik Indonesia, (Jakarta: Bina Aksara, 2001)

6 Sudargo Gautama. Pengertian tentang negara hukum, dalam Muhtadi .Pengawasan Hakim Indonesia, universitas andalas, 2008, hlm 122
}

Penegasan bahwa kekuasaan kehakiman ialah kekuasaan yang merdeka artinya terlepas dari pengaruh kekuasaan pemerintah berhubung dengan hal itu harus termaktub dalam Undang-Undang tentang kedudukan para hakim, bila dihubungkan dengan asas negara hukum maka adanya badan pemegang kekuasaan kehakiman seperti Mahkamah Agung dan Mahkamah Konstitusi tak lain sebagai penegasan bahwa Indonesia adalah negara hukum.

Seperti diketahui syarat sebagai negara hukum ialah adanya peradilan yang bebas dan tidak terpengaruh kekuasaan lain serta tidak memihak, ${ }^{7}$ yang berwenang memeriksa dan mengadili serta memberikan putusan atas perkara-perkara yang diserahkan kepadanya untuk menegakan hukum dan keadilan berdasarkan peraturan perundang-undangan.

Badan pemegang kekuasaan kehakiman harus dapat bekerja dengan baik dalam tugas-tugasnya sehingga dihasilkan suatu putusan yang obyektif dan tidak memihak dan senantiasa menjunjung tinggi hukum dan keadilan karna sejatinya kekuasaan ini adalah kekuasaan yang bebas dari pengaruh kekuasaan lain. Namun dilema yang terjadi di Indonesia dengan system rekrutmen Hakim Agung yang terkontaminasi dengan unsur politis atau masuknya politisi kedalam jajaran Hakim Agung, seperti halnya Hakim yang berasal dari Politisi seperti Gayus Lumbun. Karena perekrutan yang terjadi melalui suatu komisi dan diusulkan kepada lembaga politik maka penegakan hukum oleh Kekuasaan Kehakiman yang

\footnotetext{
7 Moh mahfud MD, Dasar dan Struktur Ketatanegaraan Indonesia, (Jakarta: Rineka Cipta, 2000), hlm 117
} 
merupakan kekuasaan yang merdeka untuk menyelenggarakan peradilan akan semakin sulit. Dengan demikian berdasarkan hal tersebut maka apakah yang dimaksud Kemerdekaan Hakim menurut Undang-Undang Dasar tahun 1945 dalam menjalankan tugasnya.

\section{Pembahasan}

Dalam usaha untuk memperkuat prinsip kekuasaan kehakiman yang merdeka berarti suatu Kekuasaan yang berdiri sendiri dan tidak dalam intervensi dari kekuasaan lainya dalam menjalankan tugasnya untuk menegakan hukum dan keadilan ${ }^{8}$ maka sesuai dengan tuntutan reformasi di bidang hukum telah dilakukan perubahan terhadap Undang-undang Nomor 14/1970 ${ }^{9}$ tentang ketentuan-ketentuan pokok kekuasaan kehakiman dengan perubahan menjadi Undang-undang Nomor $35 / 1999^{10}$ melalui perubahan tersebut telah diletakan kebijakan bahwa segala urusan mengenai peradilan baik yang menyangkut teknis yudisial maupun urusan organisasi dan finansial berada dibawah satu atap yakni Mahkamah Agung, yang harus dilaksanakan paling lambat lima tahun sejak diundangkanya UU No. 35/1999 yang berarti bahwa sejak diundangkanya undang-undang ini pembinaan badan peradilan umum, badan peradilan agama, badan peradilan militer, dan badan peradilan tata usaha negara berada dibawah Mahkamah Agung yang kemudian kembali diubah dengan UU No. 4/2004 ${ }^{11}$ dan kemudian

8 Sudarsono. Kamus Hukum, (Jakarta: Penerbit Rineka Cipta,1992), hlm 274

${ }^{9}$ LNRI 74 tahun 1970

${ }^{10}$ LNRI 147 tahun 1999

${ }^{11}$ LNRI 08 tahun 2004 belakangan ini terjadi perubahan kembali dengan UU No. 3/2009 12 tentang perubahan kedua dari UU No.14/1985 tentang kekuasaan kehakiman. Dengan demikian, telah berkali-kali perubahan undangundang kehakiman bahkan perubahan terjadi pada grand norm atau Konstitusi.

Untuk memastikan terwujudnya kekuasaan kehakiman yang merdeka diperlukan jaminan yang tegas dalam konstitusi, langkah besar yang dihasilkan dalam amandemen UUD 1945 tidak hanya menyebutkan secara eksplisit kekuasaan kehakiman yang merdeka, Pasal 24 Ayat (1) UUD 1945 menegaskan bahwa : "...kekuasaan kehakiman merupakan kekuasaan yang merdeka untuk menyelenggarakan peradilan guna menegakkan hukum dan keadilan."

Tidak hanya itu, Pasal 24 Ayat (2) UUD 1945 mengamanatkan bahwa kekuasaan kehakiman tidak hanya dilakukan oleh sebuah Mahkamah Agung tetapi juga oleh sebuah Mahkamah Konstitusi. Bahkan bagi seorang hakim, Pasal 24A Ayat (2) UUD 1945 secara eksplisit menentukan, hakim agung harus memiliki integritas dan kepribadian yang tidak tercela, adil, profesional, dan berpengalaman di bidang hukum Khusus untuk menjaga kemandirian dan integritas hakim, amandemen UUD 1945 juga memunculkan sebuah lembaga baru, yaitu Komisi Yudisial namun apakah kemerdekaan Kekuasaan Kehakiman oleh Mahkamah Agung dan Mahkamah Konstitusi telah berjalan tanpa intimidasi dari lembaga lain.

Kekuasaan Kehakiman yang dilaksanakan oleh sebuah Mahkamah

${ }^{12}$ LNRI 03 tahun 2009 
Agung dan badan peradilan yang berada dibawahnya dalam lingkungan peradilan umum, lingkungan peradilan agama, lingkungan peradilan militer, dan lingkungan peradilan tata usaha negara, dan oleh Mahkamah Konstitusi sebagaimana termaktub ketentuan Pasal 24C ayat (1) UUD Tahun $1945^{13}$ yang memiliki wewenang mengadili pada tingkat pertama dan terakhir dan bersifat final dalam menguji undang-undang terhadap UUD Tahun 1945.

Hal ini berarti kekuasaan kehakiman di Indonesia dilaksanakan oleh Mahkamah Agung dan Mahkamah Konstitusi dan diawasi oleh Komisi Yudisial dimana kekuasaan kehakiman tersebut merupakan kekuasaan kehakiman yang merdeka dan bertanggung jawab yang merupakan perwujudan dari asas kedaulatan rakyat, negara hukum, dan pemisahan kekuasaan. namun demikian, terdapat perbedaan diametral antara konsep merdeka dan bertanggungjawab dari kekuasaan kehakiman.

Makna merdeka menunjukkan tidak adanya ikatan dan tidak tunduk

13 UUD tahun 1945 amandemen ketiga, Pasal 1 ayat (2) dan (3); pasal 3 ayat (1),(3), dan (4); pasal 6 ayat (1) dan (2); pasal 6A ayat (1),(2),(3); dan (5); pasal 7A, pasal 7B ayat (1),(2),(3),(4),(5),(6), dan (7); pasal 7C; pasal 8 ayat (1) dan (2); pasal 11 ayat (2) dan (3); pasal 17 ayat( 4); BAB VIIA, pasal 22C ayat (1),(2),(3) dan (4); pasal 22D, ayat (1),(2),(3), dan (4); BAB VIIB, pasal 22E ayat (1),(2),(3),(4),(5), dan (6) pasal 23 ayat(1),(2),(3); pasal 23A; pasal 23C;Bab VIIIA; pasal 23E ayat (1),(2), dan( 3) pasal 23F; ayat (1) dan (2); pasal $23 \mathrm{G}$ ayat (1) dan (2), pasal 24 ayat (1)dan( 2); pasal 24A ayat (1),(2),(3),(4), dan (5), pasal 24B pasal (1),(2),(3), dan (4); pasal 24C ayat (1),(2),(3),(4),(5), dan (6) Undang-Undang Dasar Negara Republik Indonesia tahun 1945 pada apapun, sedangkan makna bertanggungjawab justru menunjukkan sebaliknya dalam perkataan lain, kekuasaan kehakiman yang merdeka bermakna kekuasaan yang tidak terikat, lepas, dan tunduk pada kekuasaan yang lain, sedangkan kekuasaan kehakiman yang bertanggungjawab justru bermakna kekuasaan kehakiman berada dalam kaitan dengan dan tunduk pada kekuasaan yang lain dengan demikian, terdapat kontradiksi antara kekuasaan kehakiman yang merdeka dan kekuasaan kehakiman yang bertanggungjawab.

Apabila secara esensial

kekuasaan kehakiman adalah merdeka, apakah kekuasaan kehakiman harus tetap bertanggungjawab dan apabila kekuasaan kehakiman bertanggung jawab, maka kepada siapa dan dalam hal apa kekuasaan kehakiman bertanggungjawab harus dilakukan dalam beberapa literatur ilmu hukum, dikenal adanya judicial independence (kemerdekaan yudisial) dan judicial Kemerdekaan yudisial adalah accountability (akuntabilitas yudisial).

Kemerdekaan dari segala macam bentuk pengaruh dan campur tangan kekuasaan lembaga lain, baik eksekutif maupun legislatif. Independen dapat pula diartikan sebagai "The state of quality of being independent, esp a country freedom to manage all its affair, whether external or internal, without countrol by another country. ${ }^{14}$

lebih Jadi kemerdekaan $\begin{array}{r}\text { yudisial } \\ \text { struktural }\end{array}$
kelembagaan, yakni dalam hubungan antar lembaga kenegaraan atau cabang kekuasaan.

14 Blacks law Dictionary, Seven edition (USA: West group, 1999), hlm 774 
Menurut Bagir manan, Kekuasaan Kehakiman memang lemah dibandingkan dengan kekuasaan legislatif karna secara konseptual tatanan politik. Dalam kenyataan yang terjadi kehakiman selalu tidak berdaya menghadapai tekanan politik untuk menjaga agar kekuasaan kehakiman yang merdeka tetap utuh atau tanpa campur tangan pihak/lembaga lain serta sistem administrasi, misalnya anggaran belanja. Selama sistem anggaran belanja kekuasaan kehakiman tergantung pada kebaikan hati pemerintah sebagai pemegang kas negara, maka berbagai upaya memperkuat kekuasaan kekuasaan kehakiman akan mengalami berbagai hambatan. ${ }^{15}$

Karena berbagai penyebab di atas, upaya membebaskan kekuasaan kehakiman dari pengaruh kekuasaan lain merupakan perjuangan terusmenerus. Bagaimanapun, kekuasaan kehakiman yang merdeka merupakan salah satu prinsip penting dalam negara demokrasi. Shimon Shetreet dalam Judicial Independence: New Conceptual Dimentions and Contemporary Challenges membagi independence of the judiciary menjadi empat hal yaitu ${ }^{16}$ :

\section{Substantive independence (independensi dalam memutus perkara);}

2. Personal independence (misalnya adanya jaminan masa kerja dan jabatan);

\footnotetext{
15 Bagir Manan, Restrukturisasi Badan Peradilan, dalam Majalah Hukum Varia Peradilan Tahun XX. No. 239,( Jakarta,2005 )

16 Saldi isra, Kekuasaan Kehakiman Yang Merdeka dan Bertanggung Jawab di Mahkamah Agung ( 2010)
}

3. internal independence (misalnya independensi dari atasan dan rekan kerja) dan

4. collective independence (misalnya adanya partisipasi pengadilan dalam administrasi pengadilan, termasuk dalam penentuan budget pengadilan).

Kemudian independensi yang tak kalah pentingnya ialah kebebasan atau kemerdekaan hakim dalam menfsirkan hukum, karna Mahkamah Konstitusi sebagai salah satu instrumen dalam menjalankan Kekuasaan Kehakiman memiliki suatu putusan yang bersifat final, hal ini tentunya tidak ada upaya hukum lain maka pembatasan dan pemantauan Mahkamah Konstitusi agar tujuanya tidak keluar dari tujuan utama penyelenggaraan kekuasaan kehakiman yakni menegakan hukum dan keadilan. ${ }^{17}$

Prinsip kekuasaan kehakiman yang merdeka menghendaki agar hakim terbebas dari campur tangan, tekanan atau paksaan, baik langsung maupun tidak langsung dari kekuasaan lembaga lain, teman sejawat, atasan, serta pihak-pihak lain di luar peradilan. Sehingga Hakim dalam memutus perkara hanya demi kadilan berdasarkan hukum dan hati nurani sulit memang tapi bukanlah merupakan yang hal tak mungkin bagi tegaknya Kemerdekaan Kekuasaan Kehakiman.

Dalam pandangan Hakim Agung Artidjo Alkostar, tidak ada bangsa yang beradab tanpa adanya pengadilan yang merdeka dan bermartabat. Fungsi pengadilan merupakan salah satu tiang tegaknya

17 Zulkarnain Rildwan, dalam Jurnal Konstitusi, Kompetensi Hakim Konstitusi dalam penafsiran konstitusi ( Jakarta: MK, 2011), hlm 85 
negara yang berdaulat. Salah satu elemen pengadilan adalah menyangkut faktor adanya pengadilan yang merdeka. ${ }^{18}$

Mengenai kebebasan hakim, hakim itu pada asasnya bebas, tetapi kebebasanya tidak mutlak karna kebebasan hakim tersebut diabatasi baik secara makro maupun secara mikro, faktor-faktor yang membatasi secara makro ialah sistem politik, sistem pemerintahan, sistem ekonomi, dan sebagainya faktor yang membatasi hakim secara mikro ialah Pancasila, UUD, Undang-Undang, Kepentingan umum, Kesusilaan, dan kepentingan para pihak jadi Hakim didalam memeriksa dan memutus perkara tidak boleh bertentangan dengan Pancasila, UUD, UndangUndang, Kepentingan umum, Kesusilaan, dan kepentingan para pihak $^{19}$

\section{Penutup}

Makna kemerdekaan

Kekuasaan Kehakiman baik pada Mahkamah Agung maupun Mahkamah Konstitusi dalam menegakan Kepastian dan Keadilan Hukum adalah kemerdekaan untuk memutus perkara menurut pandangan hukum hakim tanpa intervensi; kemerdekaan secara personal dalam hal jabatan dan hak yang harus diperoleh oleh hakim,; kemerdekaan secara internal Kekuasaan Kehakiman seperti pada

\footnotetext{
${ }^{18}$ Artidjo Alkostar, Membangun Pengadilan Berarti Membangun Peradaban Bangsa, dalam Majalah Hukum (Jakarta: Varia Peradilan, 2005), No. 238

19 Sudikno Mertokusumo, Kemandirian Hakim ditinjau dari struktur lembaga kehakiman, sebagaimana diposting dalam http://sudiknoartikel.blogspot.com/2008/03/ kemandirian-hakim-ditinjau-daristruktur.html diakses pada tanggal 4 juni 2012 pukul 23:22 wib
}

atasan dan rekan kerja,; kemerdekaan dalam partisipasi pengadilan termasuk dalam hal budget pengadilan; Kemudian independensi yang tak kalah pentingnya ialah kebebasan atau kemerdekaan hakim dalam menfsirkan hukum. Dan independensi kekuasaan kehakiman merupakan salah satu dasar untuk terselenggaranya pemerintah yang demokratis di bawah rule of law. ${ }^{20}$

Dan mengingat profesi hakim merupakan suatu profesi officium nobile maka harapanya dasar-dasar independensi yang diagungkan dalam menegakan hukum dan keadilan dipertegas dalam konstitusi sebagai grandnorm dalam pelaksanaan kekuasaan Kehakiman.

\section{Daftar Pustaka}

Hr, Ridwan, 2002 Hukum Administrasi Negara, PT. Raja Grafindo Persada, Jakarta.

Azhary, H.M. Tahir, 2003, Negara Hukum: Suatu Studi tentang Prinsip-Prinsipnya, Dilihat dari Segi Hukum Islam, Implementasinya pada Periode Negara Madinah dan Masa Kini. Kencana, Bogor.

Asshiddiqie, Jimly, 2007, Pokokpokok Hukum Tata Negara Indonesia, PT Bhuana ilmu popular, Jakarta.

dan
$\begin{aligned} & \text { Indonesia, } \\ & \text { Jakarta. }\end{aligned}$

Daud Busroh, Abu , 2001, Sistem Pemerintahan Republik Indonesia, Bina Aksara, Jakarta.

Muhtadi, 2008, Pengawasan Hakim Indonesia, Tesis Magister Hukum Universitas Andalas.

${ }^{20}$ Opcit hlm 85 
Mahfud MD, Moh, 2000, Dasar dan Struktur Ketatanegaraan Indonesia, Rineka Cipta, Jakarta.

Sudarsono. 1992, Kamus Hukum, Penerbit Rineka Cipta, Jakarta.

Blacks law Dictionary, Seven edition (USA: West group, 1999

Majalah Hukum (Jakarta: Varia Peradilan, 2005), No. 238.

Sudikno Mertokusumo,

http://sudiknoartikel.blogspot.c om/2008/03/kemandirianhakim-ditinjau-daristruktur.html

Majalah Hukum Varia Peradilan, Tahun XX. No. 239, (Jakarta, 2005)

Saldi Isra, Kekuasaan Kehakiman Yang Merdeka dan Bertanggung Jawab di Mahkamah Agung, Jakarta 2010

Jurnal Konstitusi, PKKPUU-MKRI, Vol. 2, 2011. 